\title{
PENDIDIKAN KESEHATAN GIGI BERBASIS ALAT PERAGA UNTUK MENINGKATKAN PERANAN GURU TK DALAM PENCEGAHAN KARIES GIGI
}

https://doi.org/10.33024/jkpm.v4i6.4448

\author{
Deviyanti Pratiwi ${ }^{1^{*}}$, Richentya Feiby Salim ${ }^{2}$, Rosita Stefani ${ }^{3}$, Rosalina \\ Tjandrawinata ${ }^{4}$, Bernard O. Iskandar ${ }^{5}$, Najla Nadiah ${ }^{6}$ \\ ${ }^{1-6}$ Fakultas Kedokteran Gigi Universitas Trisakti
}

Email Korespondensi: deviyanti@trisakti.ac.id

\begin{abstract}
ABSTRAK
Masalah kesehatan gigi yang sering terjadi pada anak usia sekolah yaitu karies. Kurangnya pengetahuan mengenai kesehatan gigi menyebabkan tingginya angka karies pada anak. Anak pada usia sekolah cenderung akan mencontoh perilaku gurunya, sehingga guru dapat berperan dalam meningkatkan pengetahuan kesehatan gigi pada anak usia sekolah. Pada masa pandemi ini, terdapat keterbatasan dalam memberikan edukasi secara langsung di lingkungan sekolah. Tujuan kegiatan ini yaitu dengan pemberian edukasi kepada guru mengenai kesehatan gigi, sehingga dapat meningkatkan pengetahuan para guru dan diharapkan para guru dapat menjadi penggerak dalam meningkatkan pengetahuan mengenai kesehatan gigi pada anak usia sekolah. Metode penyuluhan dilakukan dengan pemberian materi dalam bentuk presentasi power point secara daring melalui aplikasi zoom dan penggunaan alat peraga kesehatan gigi. Hasil penyuluhan menunjukkan adanya peningkatan pengetahuan mengenai kesehatan gigi. Setelah dilakukan penyuluhan dengan metode ini, dapat disimpulkan bahwa alat peraga dianggap efektif dalam membantu keberhasilan pendidikan kesehatan gigi serta meningkatkan pemahaman dan antusias para guru TK.
\end{abstract}

Kata kunci: kesehatan gigi, alat peraga, guru TK, karies gigi

\begin{abstract}
Dental health problem that often occurs in school-age children is caries. Lack of knowledge about dental health causes high caries rates in children. Children at school age tend to imitate the behavior of their teachers so that teachers play a role in increasing knowledge of dental health in school-age children. During this pandemic, there are limitations to providing education directly in the school environment. The aim of this activity is to provide education to teachers about dental health. So that it can increase the knowledge of teachers and it is hoped that teachers can be a pioneer in increasing knowledge about dental health in school-age children. The method was carried out by providing material in the form of an online powerpoint presentation through zoom application and the use of dental health teaching aids. The result of this activity showed an increase
\end{abstract}


in knowledge about dental health. After conducting counseling, it can be concluded that the use of teaching aids is effective in contributing to the success of dental health education and increasing the understanding and enthusiasm of kindergarten teachers.

Keywords : dental health, teaching aids, kindergarten teachers, dental caries

\section{PENDAHULUAN}

Karies gigi merupakan masalah kesehatan gigi dan mulut yang dialami hampir setengah populasi penduduk di dunia (3,58 miliyar jiwa). Berdasarkan hasil Riset Kesehatan Data (Riskesdas) tahun 2018 menyatakan bahwa gigi berlubang mendapatkan proporsi terbesar untuk masalah gigi di Indonesia. Salah satu penyebab timbulnya karies yaitu rendahnya tingkat kebersihan gigi dan mulut (Haryanto et al., 2021). Kesadaran akan kebersihan gigi dan mulut menentukan tingkat keberhasilan dalam menjaga kesehatan gigi dan mulut. (Pratiwi et al., 2020).

Masalah gigi dan mulut dapat disebabkan karena banyaknya konsumsi makanan yang manis dan mudah menempel pada permukaan gigi seperti permen. Hal ini sering terjadi pada anak usia 4 - 6 tahun tetapi tidak diiringi dengan perilaku membersihkan gigi (Haryanto et al., 2021). Usia anak merupakan saat yang penting untuk pertumbuhan dan perkembangan serta merupakan tahap awal perkembangan yang akan mempengaruhi kehidupannya (Karmelina et al., 2021). Anak pada usia 4 - 6 tahun cenderung lebih aktif dan imajinatif (Pratiwi et al., 2020). Anak yang terbiasa memiliki keadaan mulut bersih sejak usia dini cenderung akan menetapkan kebiasaan menjaga kebersihan mulut sepanjang hidupnya (Razi, P., \& Rosmawati, 2018).

Metode untuk memberikan penyuluhan mengenai kesehatan gigi dan mulut pada anak harus dibuat semenarik mungkin tanpa mengurangi pengetahuan yang disampaikan. Edukasi kesehatan gigi dan mulut membutuhkan alat peraga yang bertujuan untuk mempermudah dalam penyampaiannya (Jatmika \& Maulana, 2018). Alat peraga merupakan alat untuk membantu dalam proses pembelajaran. Penggunaan alat peraga dalam proses pembelajaran yaitu sebagai panduan yang mendukung tenaga pengajar dalam meningkatkan kemampuannya untuk menyampaikan materi, konsep dan informasi (Putri et al., 2018). Alat bantu visual yang dapat digunakan dalam penyuluhan kesehatan gigi yaitu model rahang. Salah satu fungsi model rahang yaitu dapat digunakan untuk mendeskripsikan teknik menggosok gigi yang baik dan benar. Penggunaan model rahang dalam penyuluhan kesehatan gigi dan mulut dapat menunjukkan berbagai macam bentuk gigi dan bagian dalam rongga mulut seperti gusi (Jatmika \& Maulana, 2018).

Pembentukan disipin dini pada anak dapat dimulai dari orang tua. Disiplin sejak dini yang diterapkan di lingkungan sekolah diharapkan mampu merubah perilaku anak dalam menjaga kesehatan gigi, sehingga pengetahuan yang tepat terhadap masalah kesehatan gigi yang disampaikan oleh guru dapat mendukung keberhasilan peningkatan kesehatan gigi (Simorangkir \& Sinaga, 2021). Selain orang tua, pendidikan kesehatan gigi juga perlu diterapkan oleh guru di sekolah. Hal ini karena anak usia sekolah cenderung mudah mengikuti arahan dari gurunya (Desi Andriyani, 2014). Guru tidak hanya berperan menjadi tenaga pengajar dan pendidik akademis, tetapi juga berperan sebagai pendidik karakter bagi muridnya. (Rostikawati et al., 2020). Pada umumnya, perkataan seorang guru akan diikuti dan dilaksanakan oleh muridnya. Oleh 
karena itu, guru dapat berperan dalam perencanaan program pencegahan masalah gigi dan mulut bagi muridnya (lkenasya et al., 2017).

Pada masa pandemi, tim penyuluhan kesehatan memiliki keterbatasan untuk melakukan edukasi langsung ke sekolah. Pemberian edukasi mengenai kesehatan gigi kepada para guru sekolah, diharapkan dapat menjadi penggerak peningkatan kesehatan gigi karena pada usia sekolah, anak- anak cenderung lebih mudah menerima motivasi dari para guru.

\section{MASALAH}

Masalah kesehatan gigi dan mulut di Indonesia, khususnya penyakit pada jaringan keras gigi masih tinggi. Salah satunya penyakit jaringan keras gigi adalah karies gigi yang banyak terjadi pada anak - anak dan tidak mendapatkan perawatan segera sehingga kerusakan pada jaringan keras gigi meluas dan menjadi lebih parah. Salah satu penyebab masalah kesehatan gigi dan mulut yaitu kurangnya pengetahuan yang tepat dan masih kurangnya edukasi dengan sarana yang tepat dalam masalah kesehatan gigi dan mulut.

\section{METODE}

Pelaksanaan kegiatan pengabdian kepada masyarakat ini terdiri dari tahap persiapan, tahap pelaksanaan dan tahap evaluasi. Tahap persiapan diawali dengan melakukan survei lokasi dan menentukan permasalahan kesehatan gigi yang dihadapi. Setelah itu, dilakukan pembuatan proposal kegiatan dan persiapan segala kebutuhan terkait pelaksanaan acara seperti pada diagram alur di bawah ini (Gambar 1)

Pemberian materi mengenai kesehatan gigi kepada guru TK dilakukan dengan menggunakan aplikasi zoom secara daring karena pada masa pandemi Covid-19 tidak memungkinkan untuk mengadakan kegiatan pengabdian kepada masyarakat (PkM) secara langsung. PkM dilaksanakan pada hari Sabtu 23 Januari 2021 dengan susunan acara ditunjukan pada Tabel 1. PkM ini dihadiri oleh 20 peserta. Materi pendidikan kesehatan gigi disampaikan dalam bentuk presentasi powerpoint (PPT). Sebelum kegiatan PkM dimulai, diberikan pretest dan setelah kegiatan PkM selesai, diberikan post-test sehingga dapat mengetahui peningkatan pengetahuan kesehatan gigi pada guru TK. Pre-test dan post-test diberikan dalam bentuk google form yang masing-masing terdiri dari 20 pertanyaan. Setelah kegiatan PkM terlaksana, dilakukan penyerahan poster, alat peraga dan buku edukasi kesehatan gigi selama pandemi serta sertifikat bagi para guru yang telah mengikuti acara. 
Survei mitra kerjasama dalam menentukan kebutuhan mitra dan solusi yang bisa diterapkan sesuai masalah mitra

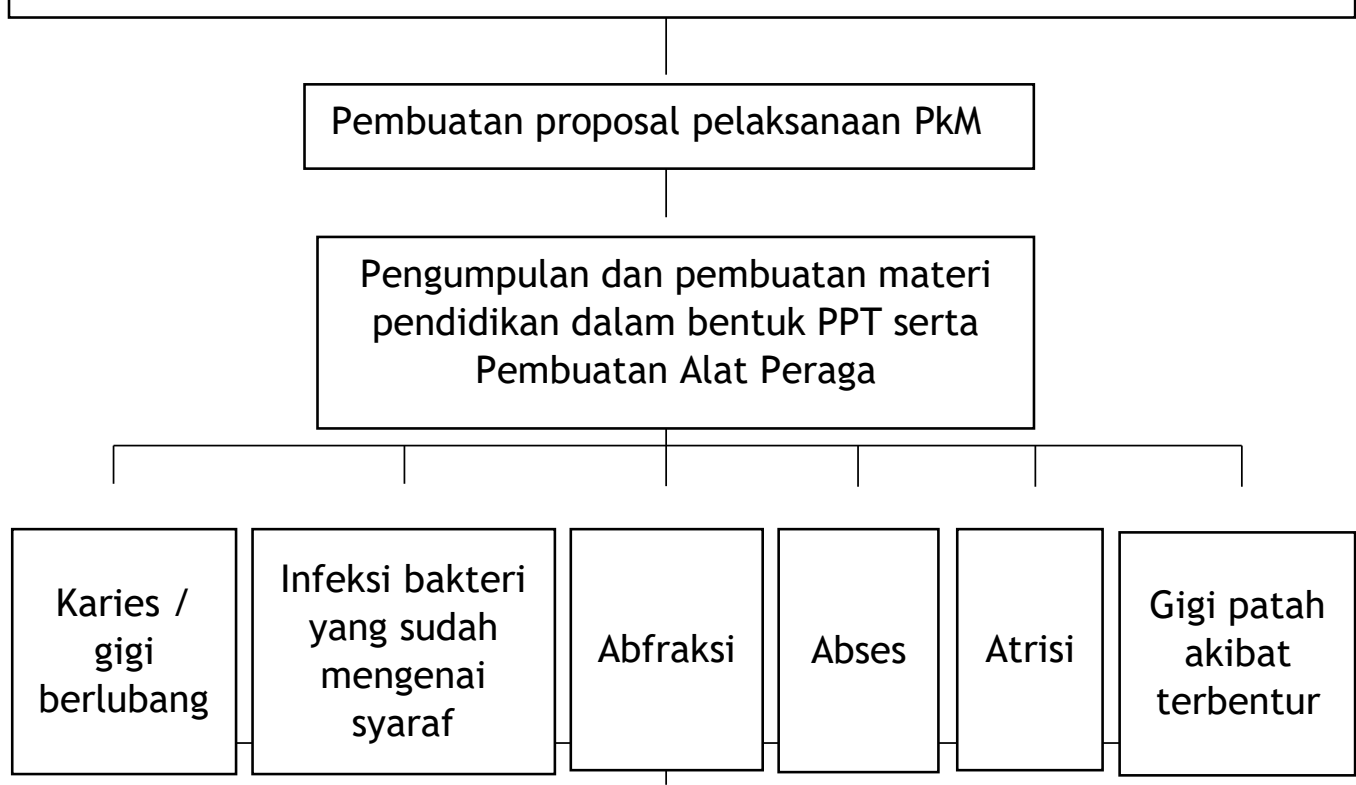

Pemberian pre-test sebelum pemberian materi dalam bentuk google form

Pelaksanaan PkM kepada guru TK Islam Al-Azhar BSD berupa pemberian materi melalui PPT mengenai kesehatan gigi

Pemberian post-test dalam bentuk google form sebagai evaluasi setelah pelaksanaan PkM dan penyerahan alat peraga Kesehatan gigi, poster, dan sertifikat

Penyerahan sertifikat kepada para peserta dan penyerahan alat peraga serta poster untuk menunjang kegiatan pendidikan gigi di sekolah

Tabel 1. Susunan Acara Pelaksanaan

Waktu

Pelaksanaa

$08.30-08.45$

$08.50-09.00$

$09.00-09.05$

$09.05-09.15$

$09.15-09.20$

$09.20-09.30$

$09.30-09.32$

$09.32-10.12$

\section{Acara}

Persiapan Panitia

Cover Judul dengan lagu (peserta di admit ke dalam zoom)

Pembukaan MC

Doa pembukaan

Sambutan ketua PkM

Sambutan kepada sekolah

Sesi foto bersama

Presentasi materi PkM 
$10.15-10.30$

$10.30-10.40$

Sesi tanya jawab

Penutupan acara dan ucapan terima kasih

\section{HASIL DAN PEMBAHASAN}

Kegiatan PkM ini diawali dengan pembukaan acara dan doa pembukaan, kemudian dilanjutkan dengan kata sambutan oleh ketua PkM yaitu drg. Rosita Stefani, Sp.KG dan sambutan oleh kepala sekolah TK Islam Al-Azhar BSD yaitu Octavia Nauli, S.Pd. Kegiatan selanjutnya yaitu pemberian pre-test untuk mengetahui tingkat pengetahuan awal para guru mengenai kesehatan gigi. Kemudian pemaparan materi dilakukan oleh drg. Bernard O. Iskandar, Sp.KG(K). Materi yang diberikan yaitu mengenai definisi dan perawatan untuk karies atau gigi berlubang, infeksi bakteri yang sudah mengenai syaraf, abfraksi, abses, gigi patah akibat terbentur, dan atrisi.
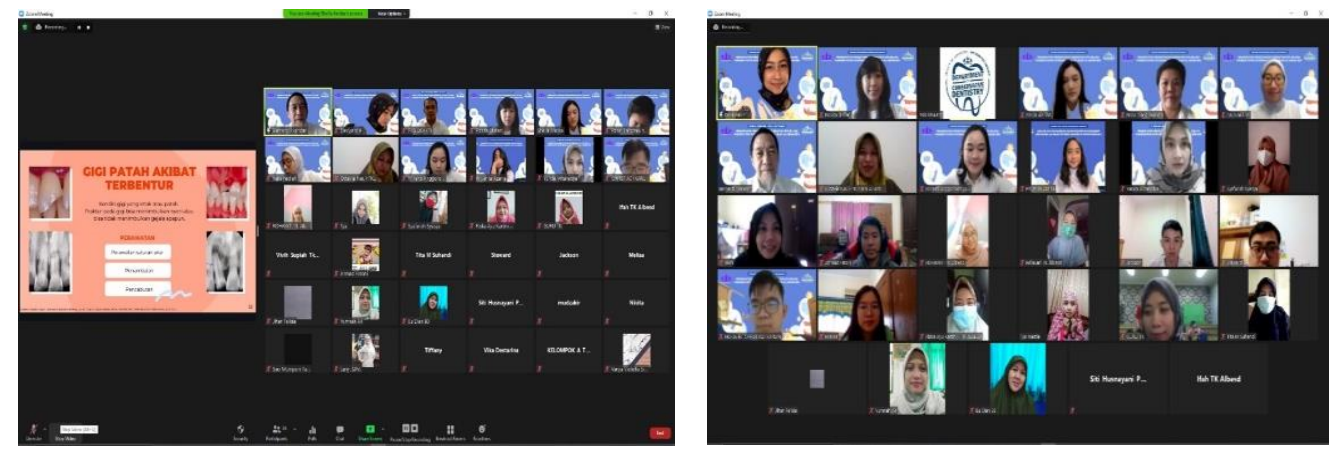

Gambar 2. Pelaksanaan Kegiatan PkM

Setelah pemberian materi, dibuka sesi tanya jawab dan pemberian posttest untuk mengetahui perubahan tingkat pengetahuan mengenai kesehatan gigi. Rata - rata nilai pre-test yaitu 72 dengan nilai tertinggi 90 dan nilai terendah 35. Sedangkan rata - rata nilai post-test yaitu 89 dengan nilai tertinggi 100 dan nilai terendah 65 (Gambar 3). Hasil post-test menunjukkan terdapat peningkatan pengetahuan guru TK Islam Al-Azhar BSD dengan ratarata sebesar $24 \%$ mengenai kesehatan gigi dan mulut setelah dilakukan pemberian materi. Hal ini menunjukkan adanya peningkatan pengetahuan tentang kesehatan gigi pada responden. 


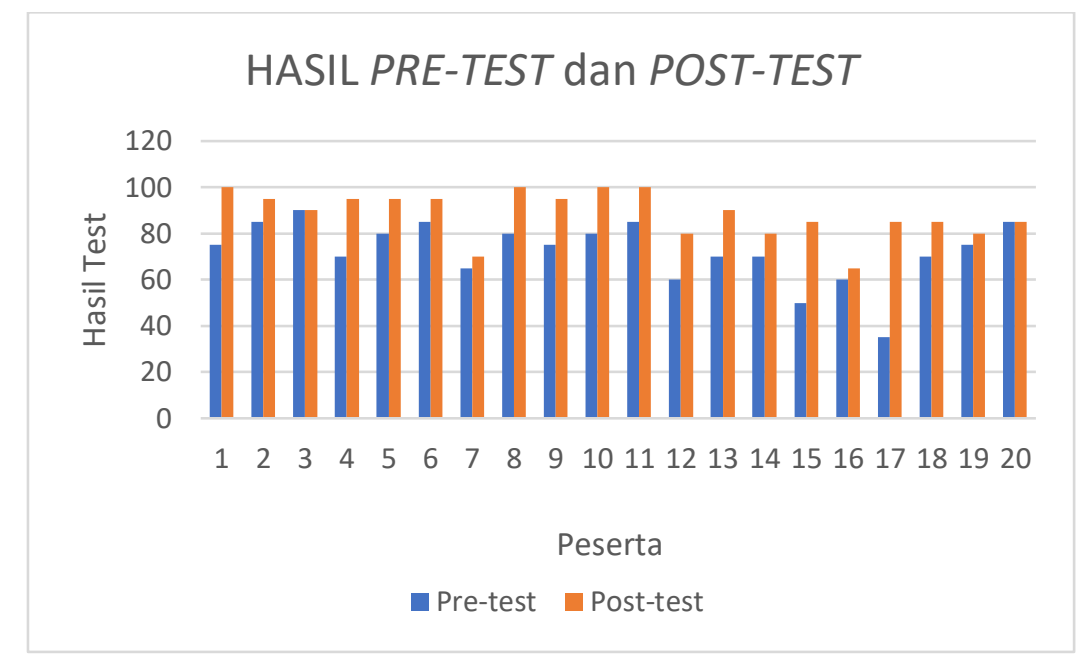

Gambar 3. Hasil Evaluasi Pre-test dan Post-test Pelaksanaan PkM

Pada pelaksanaan PkM ini digunakan bantuan alat peraga (Gambar 4) yang menggambarkan masalah kesehatan gigi. Penggunaan alat peraga ternyata mampu merangsang keingintahuan para peserta yang ditunjukkan dengan antusiasme peserta berupa banyaknya pertanyaan yang diajukan dalam sesi tanya jawab. Hal ini berujung pada peningkatan pemahaman masalah kesehatan gigi dan peningkatan nilai post-test.

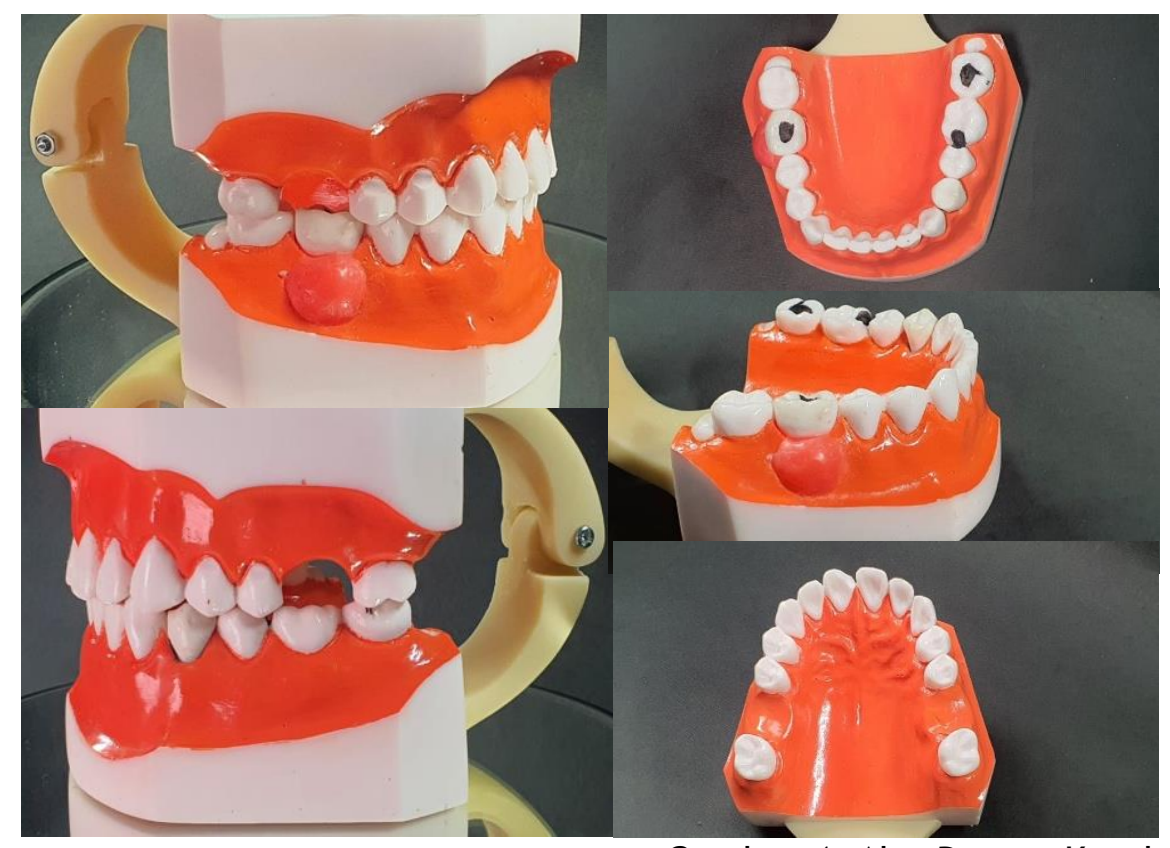

Gigi

Setelah rangkaian acara selesai dilakukan secara daring, salah seorang tim PkM yang bertugas menyerahkan alat peraga, poster, dan sertifikat langsung kepada perwakilan peserta (Gambar 5). 


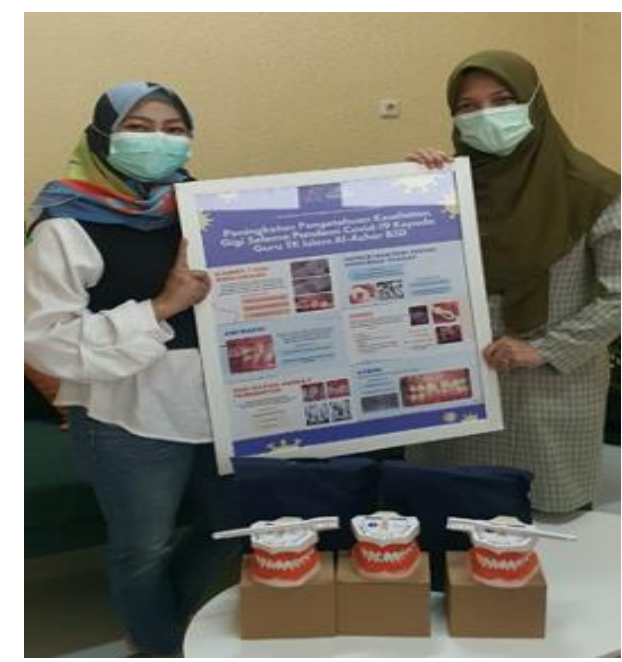

Gambar 5.Penyerahan Alat Peraga, Poster, dan Sertifikat Kepada Peserta

\section{KESIMPULAN}

Penggunaan alat peraga pada kegiatan pengabdian kepada masyarakat efektif dalam meningkatkan antusiame dan pengetahuan peserta dalam pendidikan kesehatan gigi pada guru TK. Diharapkan kegiatan ini mampu menjadikan guru TK sebagai salah satu edukator kesehatan gigi di lingkungan sekolah agar kesehatan gigi para siswa dapat menjadi lebih baik dan dapat dilakukan pencegahan karies gigi sejak usia dini.

\section{DAFTAR PUSTAKA}

Desi Andriyani. (2014). Hubungan Peran Orang Tua Dan Guru Dengan Prilaku Menyikat Gigi Murid Di Sd N 1 Perumnas Way Kandis Bandar Lampung. Jurnal Dunia Kesmas, 3(4), 39-45.

Haryanto, R., Setiasari, R., Hastuti, E. P., Saepudin, A., Rohmawati, A., Ifolisah, Laila, N., Hijriah, N., Sitompul, O. H., Nurlaela, R., Annisa, R., Wulandari, R. N., Gristine, S., \& Wibowo, Y. (2021). Meningkatkan Pengetahuan Cara Menggosok Gigi Dengan Baik Dan Benar Melalui Penyuluhan Pada Anak. Jurnal Kreativitas Pengabdian Kepada Masyarakat (Pkm), 4, 393-399.

Ikenasya, D. F., Herwanda, \& Novita, C. F. (2017). Tingkat Pengetahuan Guru Mengenai Kesehatan Gigi Dan Status Karies Gigi Murid Sekolah Dasar Dengan Ukgs Dan Tanpa Ukgs (Studi Pada Sdn 16 Dan Sdn 49 Banda Aceh). Journal Caninus Denstistry, 2(3), 131-136.

Jatmika, S. E. D., \& Maulana, M. (2018). Dental And Oral Health Education For Elemetary School Students Through Patient Hygiene Performance Index Indicator. International Journal Of Evaluation And Research In $\begin{array}{lll}\text { Education } & \text { (Ijere), }\end{array}$ Https: / /Doi.Org/10.11591/ljere.V7i4.14856

Karmelina, S., Setiasari, R., Wahyuningsih, I. P., Nurseha, Febrianti, A., Nurbiantoro, D. Aji, Setiawati, H., Castirih, Efendi, I., Filianata, O., Susilawati, Y., Muharom, F., Yuliana, E., Amalia, M., \& Sulistyo, Y. (2021). Meningkatkan Pengetahuan Cara Senam Otak Untuk Konsentrasi Dan Daya Ingat Pada Anak Usia 5-12 Tahun. Jurnal Kreativitas 
Pengabdian Kepada Masyarakat (Pkm), 4(3), 470-474. Http://Dx.Doi.Org/10.1016/J.Encep.2012.03.001

Pratiwi, D., Ariyani, A. P., Sari, A., Wirahadikusumah, A., Nofrizal, R., Tjandrawinata, R., Soulisa, A. G., Wijaya, H., Sandra, F., Gigi, K., Gigi, F. K., \& Trisakti, U. (2020). Penyuluhan Peningkatan Kesadaran Dini Dalam Menjaga Kesehatan Gigi Dan Mulut Pada Masyarakat Tegal Alur , Jakarta Community Services To Increase Dental And Oral Health Early Awareness In Tegal Alur , Jakarta. Jurnal Abdi Masyarakat Indonesia, 2(2), 120-128.

Putri, C. A., Rusilowati, A., \& Subali, B. (2018). Eclips Props To Probe Motivation Of Visual Impairment Students In Learning Science. Journal Of Primary Education, 8(4), 42-48. Https: / /Doi.Org/10.15294/Jpe.V7i3.24388

Razi, P., \& Rosmawati, R. (2018). Perbandingan Efektivitas Edukasi Kesehatan Gigi Dengan Metode Bermain , Video Dan Boneka Dalam Meningkatkan Keterampilan. Jurnal Bahana Kesehatan Masyarakat, 2(2), 101.

Rostikawati, Y., Aeni, E. S., \& Wuryani, W. (2020). Peran Guru Dalam Membentuk Karakter Siswa Melalui Pembelajaran Kesantunan Berbahasa Di Media Sosial. 03(01), 49-59.

Simorangkir, M. R. R. , \& Sinaga, D. (2021). Peningkatan Pemahaman Orangtua Siswa Usia Dini Tentang Disiplin Diri Untuk Mengarahkan Hati. Jurnal Kreativitas Pengabdian Kepada Masyarakat (Pkm), 4(1), 42-48. 